\title{
Why do agricultural co-operatives fail to attract youth and create rural employment? Evidence from a case study of Zanokhanyo in Butterworth, Eastern Cape
}

Zantsi, S. ${ }^{1}$

Corresponding Author: S. Zantsi. Email: siphezantsi@yahoo.com

\section{ABSTRACT}

In the National Development Plan, cooperatives and agriculture development are identified as possible solutions for addressing rural poverty and unemployment, especially among the youth. However, according to most research/literature, agricultural cooperatives fail for many reasons, including but not limited to lack of capital, incompetent management and organizational deficiencies. This study applied a qualitative analysis to the qualitative data using a case study of Zanokhanyo Food Security Cooperative (ZFSC) in Ndabakazi, Butterworth. Interviews with the project members, ex-members, extension officers and youth were conducted through a semi-structured questionnaire administered in IsiXhosa. According to the results, lack of intensive production resulting in very low incomes is one of the reasons why projects such as ZFSC fail to attract young people and provide employment for rural people. Agricultural extension advisory services play a very limited role because of their generalist approach; they lack depth of knowledge about diverse agricultural subject areas. This study recommends that agricultural extension and the farmers' support system be improved by employing or outsourcing specialists to cater to the needs of agricultural cooperatives in order to improve the productivity and income of agricultural cooperatives.

\section{INTRODUCTION}

According to the International Cooperative Alliance (ICA) (2013), cooperatives are 'autonomous association of persons united voluntarily to meet their mutual economic, social, and cultural needs and aspirations through a jointly-owned and democratically-controlled enterprise' ii. There are various types of cooperatives around the world and in South Africa, among them agricultural cooperatives, the focus of this article. Agricultural cooperatives produce, process and market agricultural products and supply agricultural inputs and services to their members (DAFF, 2015). Like the rest of the agricultural sector, agricultural cooperatives are envisaged to play an important role in reducing poverty (NPC, 2011).

Like many developing nations, South Africa battles poverty. Empirical evidence suggests that $95 \%$ of people living in all facets of poverty (multidimensional) is widely spread among Black Africans, households headed by women and people living in rural areas (Fransman \& Yu, 2019;

\footnotetext{
${ }^{1} \mathrm{PhD}$ student, Department of Agricultural Economics, Stellenbosch University, Private Bag X1, Matieland, 7602, Stellenbosch, South Africa; Agroscope, Socio-economic group, Tänikon 1, Ettenhausen 8356, Switzerland.Tel +41 584818373 E-mail: siphezantsi.yahoo.com: https://orcid.org/0000-0001-9787-3913
} 
Cheteni et al., 2019). The Eastern Cape province and KwaZulu Natal are the poorest provinces in the country. One half of all people living in poverty in South Africa live in one of these two provinces (Fransman \& Yu, 2019). Moreover, this multi-dimensional poverty correlates with high unemployment rates, particularly among the youth (StatsSA, 2017; De Lannoy et al., 2018; Fransman \& Yu, 2019).

Agriculture is often viewed as one possible solution to address poverty and unemployment especially in the rural areas (Machete, 2004; Lyne et al., 2018; Magano et al., 2013; Wessels $\&$ Nel, 2016). The National Planning Commission's National Development Plan places agriculture at the centre of rural economic growth, development and employment creation (NPC, 2011). In this regard, across the globe, agricultural cooperatives have been widely acknowledged as a vehicle to uplift poor people from deep poverty in developing countries, including South Africa (see Ortmann \& King, 2007; Mojo et al., 2017; Sebhatu et al., 2020; Yobe et al., 2020).

On the one hand, the South African government has invested a significant sum of resources into agricultural cooperatives. In 2014-15, the Department of Agriculture, Fisheries and Forestry (DAFF) spent R178 million to support agricultural cooperatives. On the other hand, there is overwhelming evidence of failed agricultural cooperatives and few success stories despite an increase in registered cooperatives in South Africa. A 2009 report by the Department of Trade and Industry (DTI) showed that the mortality rate of food and agricultural cooperatives was $89 \%$ compared to the $11 \%$ survival rate (DTI, 2012).

Besides the National Cooperative Association of South Africa (NCSA) survey in 2001 and a 2020 study by Yobe et al., few studies have evaluated the impact of agricultural cooperatives at the national level. In the Eastern Cape, there is also a paucity of such studies. Many studies have focused on specific cases (e.g. Magano et al., 2013; Dyaluvane, 2015; Gwiriri \& Bennett, 2020), in this way limiting the scope of knowledge about the performance of agricultural cooperatives. Nevertheless, each specific case, though only making a small contribution individually, adds to the existing body of knowledge. Likewise, this article attempts to give insight into why the Zanokhanyo Food Security agricultural cooperative has failed to provide employment and attract youth.

\section{LITERATURE REVIEW: YOUTH UNEMPLOYMENT, AGRICULTURAL COOPERATIVES AND THE ROLE OF AGRICULTURAL EXTENSION}

\subsection{Youth unemployment in South Africa}

Like poverty, unemployment is a serious challenge facing South Africa. According to Statistics South Africa (2020), in the fourth quarter of 2019, 6.73 million people were unemployed, representing $29.1 \%$ of the country's population. The same report shows that the Eastern Cape had a $40 \%$ unemployment rate. Of concern regarding the unemployment challenge is the youth, 
by far the most affected age group - about $42 \%$ of people between ages 18-25 were unemployed (StatsSA, 2015). Figure 1 below, from the Youth Unemployment Report, summarises the picture of youth unemployment in the country by age cohorts from the year 2000 to the year 2016 .

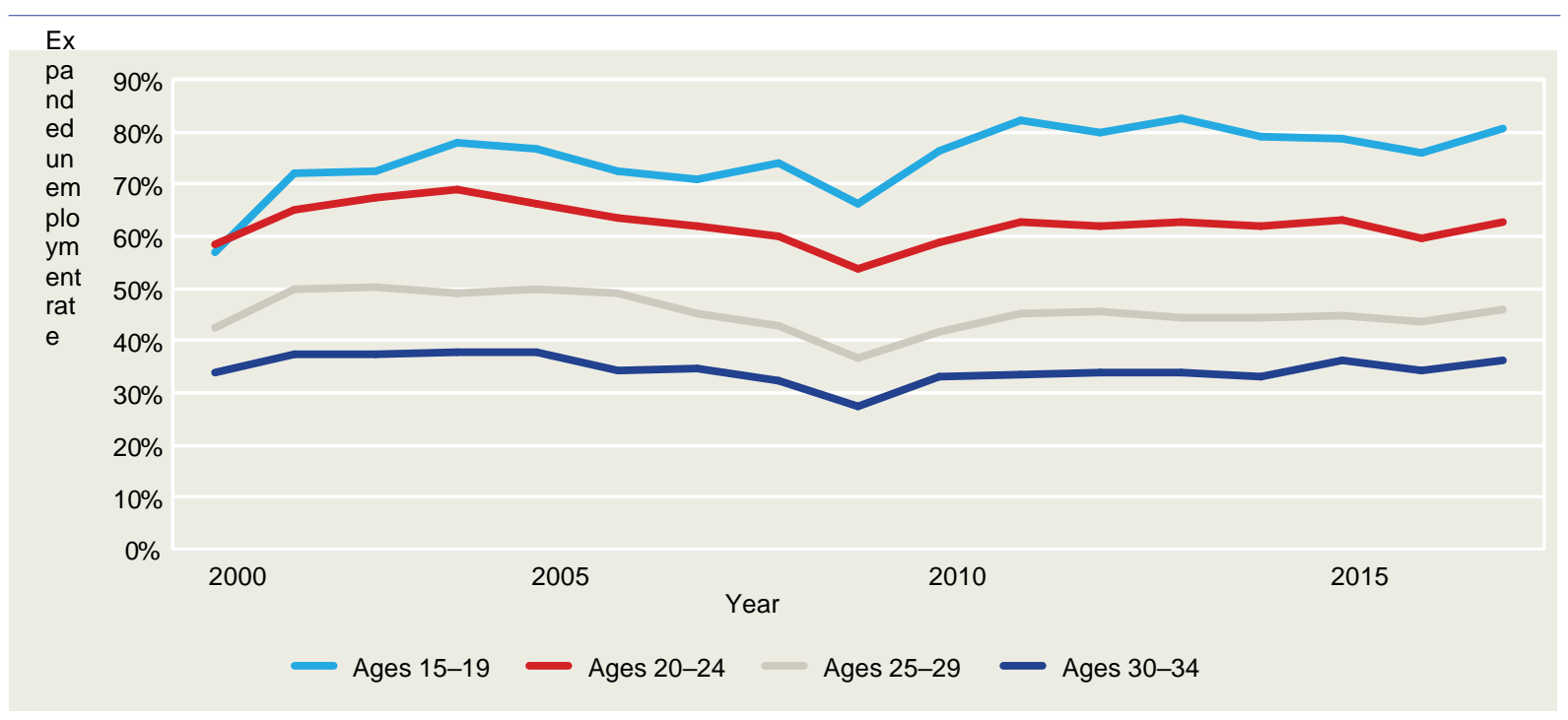

Figure 1 Youth unemployment in South Africa from 2000-2016

Source: De Lannoy et al., 2018:8

The analysis in Figure 1 from De Lannoy et al. (2018) depicts that across all of the youth age groups, unemployment started to drop between 2004 and 2008. However, since the global economic crisis of 2009, it has returned to the levels of the early 2000s. Although there has been some economic recovery since 2009 , youth employment rates have not recovered, and certainly, for the youngest age cohort (15-29-year-olds), the unemployment rate has worsened. According to De Lannoy et al. (2018), the increases are mostly driven by increased discouragement among young people regarding seeking employment. This discouragement is associated with the cost of seeking work and lack of qualifications, skills and work experience, including a lack of social networks (Patel et al., 2020).

\subsection{Agricultural cooperatives}

There are various types of cooperatives around the world and in South Africa; among those, there are also agricultural cooperatives. Agricultural cooperatives are those that produce, process and market agricultural products and supply agricultural inputs and services to their members (DAFF, 2015). According to the ICA (2013), there are seven principles guiding the operations of cooperatives:

- Voluntary and open membership

- Democratic member control

- Member economic participation

- Autonomy and independence 
- Education, training and information

- Cooperation among cooperatives

- Concern for community

These principles are based on the values of self-help, self-responsibility, equality, equity and solidarity (ICA, 2013). The South African cooperatives, according to the Cooperative Act of 2005, are also formed based on these values. Cook and Illiopoulos (2000) refer to cooperatives formed on the above principles and values as traditional cooperatives. While there is a lack of reliable data on cooperatives in the country due to poor or lack of coordination among cooperatives, a Department of Agriculture and Forestry report shows that KwaZulu-Natal, Limpopo, North West and Mpumalanga provinces have the highest number of agricultural cooperatives, in descending order. The Eastern Cape has the fifth most agricultural cooperatives of any province, with 202 agricultural cooperatives (DAFF, 2015). In terms of commodities, crop cooperatives constitute most of the agricultural cooperatives in South Africa, followed by livestock cooperatives. In the Eastern Cape, the same trend is observable, with 61 crop cooperatives and 36 livestock cooperatives (DAFF, 2015).

\subsection{The rationale behind cooperatives}

Globally, cooperatives continue to be viewed as one of the catalysts of promoting economic growth by creating employment, increasing income and reducing poverty (Mojo et al., 2017; Sebhatu et al., 2020). In South Africa, cooperatives have also played a crucial role in the development of white commercial farmers in South Africa, mainly during the apartheid era (Ortmann \& King, 2006). The post-apartheid government has also acknowledged the potential benefits of cooperatives. Cooperatives have many benefits for both the government and citizens given the limited resources of the government and high unemployment and poverty levels in South Africa. Cooperatives offer an opportunity to address all these issues at once through achieving economies of scale, economies of scope, increasing bargaining power, community participation and development, stability, innovation and legal protection, which are generated when people come together rather than focusing on individuals (DTI, 2012). For example, resources, such as land, machinery and transport, are easily accessible when farmers pool their resources together, since the costs are shared. Furthermore, the markets are better secured in a group, especially given the nature of small-scale farming in South Africa. ${ }^{2}$ Moreover, the services that farmers require from the government - for example, inputs, machinery and extension services - are more affordable than when the government funds individuals. The end goal of these benefits is economic growth and employment creation (Wessels \& Nel, 2016). In 2012, the DTI launched an integrated strategy for the development and promotion of cooperatives with the following vision:

\footnotetext{
${ }^{2}$ Small-scale farmers produce low outputs individually and are scattered over wide geographical areas (see, for example, Aliber, 2019b).
} 
The vision of cooperatives is to move towards a growing, self-sustainable and integrated sector supported by all stakeholders, contributing to economic growth, poverty reduction and employment creation, as well as assisting in bringing about economic transformation and equitable society in South Africa (DTI, 2012: 11).

Cooperatives also form part of the Comprehensive Rural Development Programme (CRDP) approved in 2009. The CRDP focuses on, among other things, the establishment of rural business initiatives, agro-industries and cooperatives in villages and small towns. The success of cooperative can be measured more than one dimensions, for example, economic and social dimensions (Mann \& Stoinescu, 2020). While the cooperative vision in South Africa is clearly envisaged to improve the livelihoods of the poor, there are very few success stories.

\subsection{Reasons behind cooperative failure in South Africa}

Ortmann and King (2006) contend that an understanding of the reasons behind the failure of cooperatives in the former homelands is imperative in order to proactively avoid similar occurrences in the future. Poor management, lack of training, conflict among members and insufficient funds were found to be the major causes of failure in Limpopo by van der Walt (2005). This sentiment was also shared by van Niekerk (1988). Both these authors further state that members of failed cooperatives did not understand the purpose of the cooperative, how it should function and what their rights were. They attribute this to a lack of education and training. These aforementioned variables, together with poor managerial aptitude, age, size and governance, were found to be the major influential factors in agricultural cooperative efficiency, the lack of which ultimately results in cooperative failure (Yobe et al., 2020). While a majority of agricultural cooperatives in South Africa are financially inefficient (Yobe et al., 2020), the efficiency of agricultural cooperatives is an important factor, as it determines the profits and dividends for each member and contributes to the members' livelihood. Table 1 below summarises some of the commonly cited reasons for agricultural cooperative failure in South Africa.

Table 1 Key reasons why agricultural cooperatives fail in South Africa

\begin{tabular}{|l|l|}
\hline Reason for coop failure & Author/studies \\
\hline Lack of/poor management & $\begin{array}{l}\text { Machete, 1990; Van der Walt 2005; van Niekerk, 1988; DTI, } \\
\text { 2012; Dlamini, 2010; Wessels \& Nel, 2016; Emanuel \& Nhlanhla, } \\
\text { 2014; Yobe et al., 2020; Manenzhe, et al., 2020 }\end{array}$ \\
\hline Conflict among members & DTI, 2012; Wessels \& Nel, 2016; Nefale, 2016 \\
\hline Insufficient/inadequate funds & Van der Walt, 2005; Emmanuel \& Nhlanhla, 2014 \\
\hline Subsistence nature of farming & Machete, 1990; Dyaluvane, 2015 \\
\hline $\begin{array}{l}\text { Market access \& marketing } \\
\text { skills }\end{array}$ & $\begin{array}{l}\text { DTI, 2012; Wessels \& Nel, 2016; Dlamini, 2010; Mazibuko \& } \\
\text { Satgar, 2009; Chibanda et al., 2009; Nefale, 2016; Dyaluvane, } \\
\text { 2015 }\end{array}$ \\
\hline Lack of/low education & Ortmann \& King, 2007; Dlamini, 2010; Chibanda et al., 2009 \\
\hline Free rider problem & Ortmann \& King, 2007; Dlamini, 2010 \\
\hline
\end{tabular}




\begin{tabular}{|l|l|}
\hline Insecure property rights & Ortmann \& King, 2007; Dlamini, 2010 \\
\hline $\begin{array}{l}\text { Lack of transparency, } \\
\text { accountability and democratic } \\
\text { governance }\end{array}$ & Gwiriri \& Bennett, 2020 \\
\hline
\end{tabular}

Source: Author's synthesis of literature

Aliber (2019b) has described most of the project approaches to the smallholder development that plays a part in agricultural cooperatives as problematic and dysfunctional. He alludes that, in some instances, people group themselves for the sake of attracting funding rather than because they are interested in the projects. He further laments that this is exacerbated by the culture of entitlement of smallholder farmers.

\subsection{Role of agricultural extension in cooperative development}

Agricultural extension is defined as 'all the different activities that provide the information and advisory services that are needed and demanded by farmers and other actors in agri-food systems and rural development' (Christoplos, 2010: 2). Agricultural extension has an important role in farmer and agricultural cooperative development (Gwiriri \& Bennett, 2020). This is especially true for smallholder farmers in South Africa, particularly in the Eastern Cape, where a majority of smallholders rely on public agricultural extension (Aliber et al., 2017). The role of agricultural extension is even greater for agricultural cooperatives for numerous reasons. First, the state invests significant sums of money in agricultural cooperatives, and therefore, to ensure the growth of this investment, cooperatives should perform efficiently. Second, the state saves resources through cooperatives because, as previously argued, cooperatives use fewer resources to help many farmers at once. This is particularly true for the higher extension-tofarmer ratio of 1:965 among smallholders (see Lukhalo, 2017). Furthermore, agricultural cooperatives need more capabilities to succeed as we have seen in the reasons for their failure (Table 1) - these skills range from managerial skills, conflict management and resolution skills and marketing and production skills beyond subsistence. However, the question is how well is public agricultural extension playing its role in supporting agricultural cooperatives? Does it have enough capable human capacity to perform this huge and important role, and if the answer is 'no', what should be done to provide advisory support to agricultural cooperatives? These are some of the important questions agricultural extension policy makers should carefully contemplate. To address these questions, some lessons can be taken from outsourced agricultural extension, which seems to be doing better than public extension (see for example Lyne et al., 2018; Baiyegunhi et al., 2019).

\section{DATA, APPROACH AND THE CASE STUDY - ZANOKHANYO FOOD SECURITY COOPERATIVE (ZFSC)}

Interviews were conducted in July 2019 with a) three current members of ZFSC, 2) five dropped-out members and 3) ten unemployed young people in Ejojweni village. Young people were defined as those between the ages of 18-35 years and unemployed as people who have 
not been working but were looking for employment at the time of the survey (De Lannoy et al., 2018). A semi-structured questionnaire with open-ended questions was administered in the local language (isiXhosa). The project had close to 60 members when it was still more active, according to the respondents. However, other respondents who dropped out had passed away. While this sample cannot be deemed well representative, it is at least big enough to allow some reasonable analysis. The author visited the project site and then used data from Statistics South Africa and Google Maps to get further details about the study site. The approach to data analysis adopted here is basic qualitative analysis.

ZFSC is located in Ejojweni, a Butterworth village. The cooperative was established in 2002 by the Department of Social Development in collaboration with the provincial Department of Agriculture for the Ndabakazi community, comprising the three villages in Table 2 below.

Table 2 ZFSC beneficiary villages and their details

\begin{tabular}{|l|l|l|l|l|}
\hline Village & $\begin{array}{l}\text { Number of } \\
\text { households }\end{array}$ & Population & Working age & Dependence ratio \\
\hline Ejojweni & 168 & 645 & $51.2 \%$ & $95.2 \%$ \\
\hline Komkhulu & 169 & 675 & $50.5 \%$ & $97.9 \%$ \\
\hline Elengeni & 106 & 469 & $55.2 \%$ & $81.1 \%$ \\
\hline Total & 443 & 1,789 & - & - \\
\hline
\end{tabular}

Source: Statistics South Africa, 2011.

Ndabakazi, like many rural villages, is characterized by poverty and alarmingly high unemployment rates as shown by the high dependence ratio (see Table 2). However, there is a significant amount of arable land, although it is unevenly distributed (Zantsi, 2016). There is a growing trend of declining arable field cultivation currently taking place in many parts of the Eastern Cape (Blair et al., 2018), including Ndabakazi (see Zantsi \& Bester, 2019). The Department of Social Development initiated the project ZFSC, through which it negotiated with the owners of fields to sign an agreement stating that their fallow fields may be used by the project to produce crops, poultry and piggery. The project has access to 415 hectares of land with two buildings for raising poultry and pigs (see Figure 2). According to the few (3) remaining members, the project started with approximately 60 members, of which $90 \%$ were old people, with youth only making up around $10 \%$ of the members. 


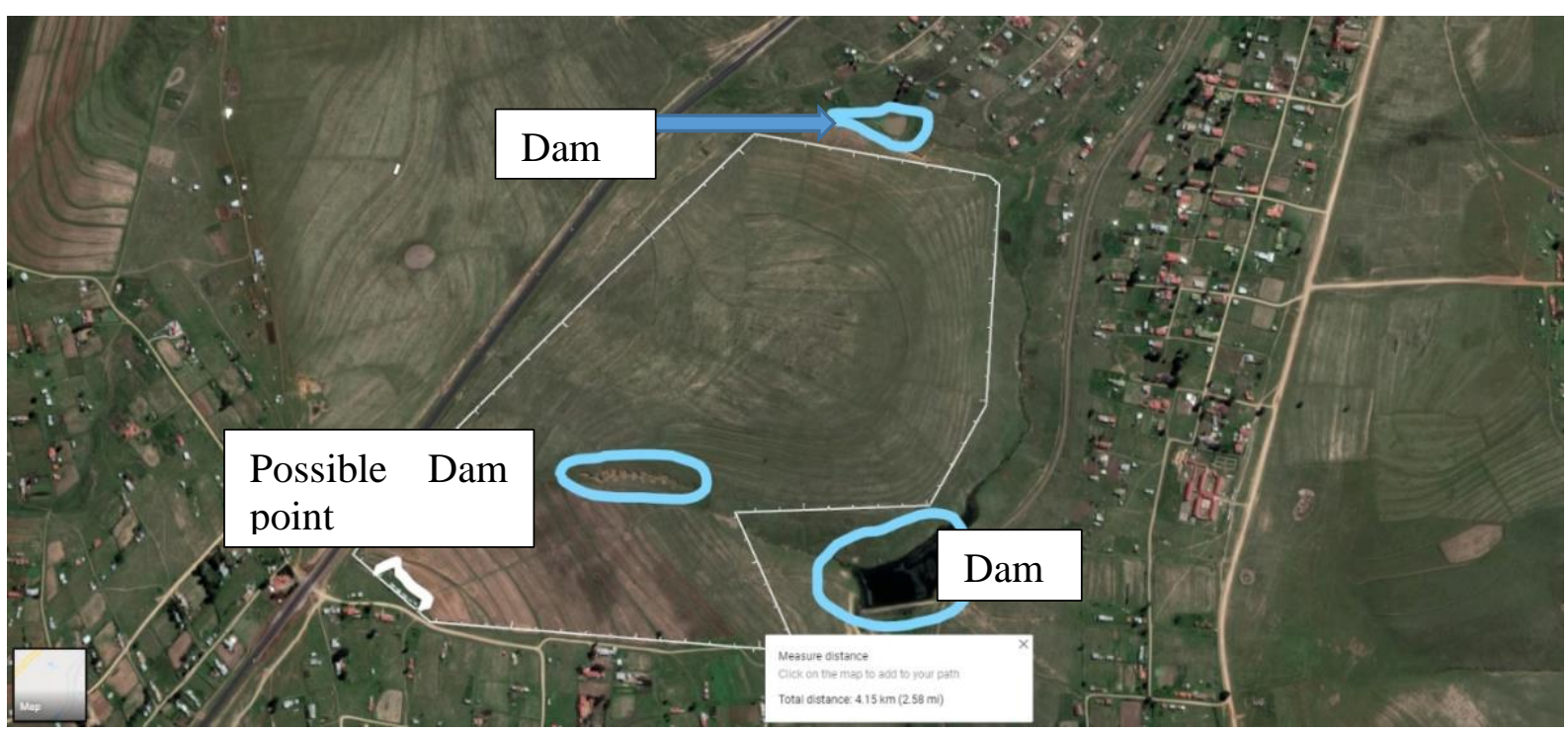

Figure 2 Map showing area of land ZFSC to which has access and nearby dams

Source: Google Maps

To date, only three members remain with the project, and only minimal production takes place. At the time of the visits, only a small batch of broilers (less than50) were raised, and only small patches of fields were ploughed (not planted), as shown in Figure 2. The members complained about a lack of operational budget and human capital, frequent droughts and unreliable markets. The remaining members were three females, two in their 50s and one in her 60s. The project owned two tractors with ploughs, discs, a boom spray and a trailer. Recently the project received funds from an NGO and bought a bakkie. Unfortunately, efforts to obtain production and membership records over the years were not successful. The researchers also noticed some reluctance from the chairperson to share such information with him. The reason for this were not clear. Two extension officers or agricultural advisors were also interviewed to get insights about agricultural coops in the district and specifically about ZFSC. The main question asked was why agricultural coops fail and fail to attract youth. Follow up questions were asked for clarity and elaboration. Among the interviewed officers, one has worked with ZFSC from 2010 to date, taking over from a retired officer, who has worked with ZFSC from its inception. The other officer works with nearby coops in the districts in other wards.

\section{PRODUCTION PERFORMANCE OF ZFSC AND HOW IT FAILS TO ATTRACT YOUTH}

Results from interviews conducted with members, ex-members and young people around the village of Ejojweni confirmed many of the reasons associated with agricultural cooperative failure identified in literature. Maize, dry beans and vegetables were the major crops once produced by ZFSC while it was still more active. In addition to these crops, ZFSC also produced pigs and broilers. Although production statistics could not be found, it was mentioned that production was at a reasonable scale, and most of the produce was sold to generate income 
for members. The tractor was also used to generate income by hiring it out to plough gardens and fields around the nearby villages at a cost of about R350 per garden or per hour for a field. Regarding social relations and dividends, results from interviews show that in ZFSC, like many cooperatives, there were conflicts among members about management of funds, sharing of profits and task allocation. This finding resonates with the noted lack of transparency, poor governance and democratic rule in agricultural cooperatives that betray the imbalanced power relations reported by Gwiriri and Bennett (2020). The youth and the majority of the exmembers of ZFSC complained that they received very little money from the project. Insights from the interviews show that, depending on how frequently a member had been present on working days, the income per member ranged between R1500 and R2000 annually. Respondents did claim that in addition to receiving this income, members also received farm produce, such as unmarketable vegetables or maize cobs; these results corroborate findings from Magano et al. (2013) about the sharing of produce among agricultural cooperative members. These benefits notwithstanding, respondents also raised some complaints about how ZFSC was run. One ex-member youth complained that when the project was still active, the physical workload tended to fall on their shoulders (because the majority of the members were elderly persons) while dividends were shared equally. The tone of the responses suggests that they think this was unfair. This was not only flagged as a problem in ZFSC - a similar finding in Limpopo was reported in Thaba's (2016) study among the dysfunctional projects.

The low share of dividends mostly resulted from the fact that production was not intensive, and crop production was largely dependent on dryland production. For example, crop production occurred only during rainy seasons. Other contributing factors included droughts in bad years and late arrival of funds, which resulted in missing the production season and suffering financial constraints. In the case of poultry and piggery, inability to secure contracts with formal markets and a lack of intensive production skills were major challenges that seemed to be prominent according to respondents. According to rough estimates from Uys' (2018) article on poultry housing basics, the poultry houses are big enough to accommodate a rotation of four batches (100 chickens per batch). Therefore, if this production plan could be fully tapped by ZFSC with a reliable market, it could significantly improve the profits of the project and, in turn, the income of its members. Moreover, the income could be earned on a monthly basis, making it a reliable source of income for members trying to make ends meet. With regard to crops, irrigation would go a long way toward intensifying production. There are two nearby dams - one needs to be rebuilt, however. None of these dams are used for irrigation. While this could be limited by funding constraints, there was little indication that this was under consideration and planned for the future.

\subsection{Perspective of unemployed youth who are not and have never been members of ZFSC}

In addition to young people who were members of ZFSC, youth who have never been a part of ZFSC were also interviewed. These respondents expressed a general sentiment of the difficulty 
of finding employment. The underlying reasons included lack of qualifications, work experience and network connections - similar to what other studies reported (Patel et al., 2020). According to respondents, to deal with this frustration, a majority of young people, particularly males, flock to local taverns to share beers or other alcoholic drinks. While there was a preference for non-agricultural work among the respondents, a majority (80\%) did not mind working in agriculture, as they had already done so part-time in a similar agricultural cooperative established in the area a few years ago. What seemed to be important to the respondents was work that pays regularly - for example, per day, per week or per month which was not the case in ZFSC. These findings resonate with what the existing literature reports - that youth are reluctant to work in the fields with their parents, and in the rare cases that they do, they demand compensation (Hull, 2014; De La Hey \& Beinart, 2016).

\subsection{Extension advisory service to ZFSC}

Agricultural extension is envisaged to play a key role in the development of agricultural cooperatives by providing appropriate advice. However, in the case of ZFSC, expert advice on improving productivity seemed to have been lacking. According to the members of ZFSC, their assigned extension officers who were responsible for advising the project never brought the idea of irrigation and broiler rotation production to the attention of the members. This is probably the first officer who worked with ZFSC from its inception until 2010. The failure of extension officers to bring these suggestions could mean two things: one, that cooperatives receive less attention from the agricultural advisors (this was confirmed by the respondents that they see advisors after 3-6 months); and two that agricultural advisors are simply not specialists in intensive crop and poultry production. The first point relates to the high ratio of extension officer to farmer (1:965) pointed out by Lukhalo (2017).

When asked about the reasons for failure of agricultural cooperatives, the interviewed extension officers confirmed the reasons cited in the literature, conflicts, lack of funds, poor productivity and lack of youth involvement as well as free rider problems. The other reason was that these coops are formed for the sake of attracting funding by recruiting or convincing uninterested people in farming to join then when funds have been finished only a few people continue with the project. This point resonates with findings from Aliber (2019b). The extension officer working with ZFSC, did confirm however, that low productivity and production due to reliance on rainfall limits the project from attracting youth and other people from joining ZFSC. The officer also confirmed that he has suggested installing of irrigation from the nearby dam (see Figure 2), but funding is still a challenge. However, he had not suggested broiler rotation, probably because he specialise on crop production. This runs against the suggestion by Terblanche (2008) that extensionists should at least be experts in one field of agriculture. Reliance solely on project members for the management of cooperatives is common in South Africa (see Magano et al., 2013). The aforementioned authors also view this as a setback for creating more employment. This is because, as seems to be the case in ZFSC, project members and managers do not have the skills for intensive farming, and they tend to 
rely on subsistence methods of production (Machete, 1990). This leads to poor productivity and less competitiveness, which are crucial in the rest of the South African agricultural sector (D'Haese \& Bostyn, 2001; Genis, 2015). On the one hand, Manenzhe, Zwane and Van Niekerk (2020) argue that sound business knowledge and farming skills are key to the success of cooperatives, while on the other hand, Magagula and Tsvakirai (2020) have provided evidence of youth's interest in agriculture and agribusiness participation. The combination of these ideas may be indicative of the potential of that exist in agricultural cooperatives for creating employment and business opportunities for young people.

\section{CONCLUSION AND RECOMMENDATIONS}

Agricultural cooperatives indeed have the potential to increase the income of rural households and create employment while transferring skills to the youth. However, this needs to be facilitated through support and relevant extension advice as well as committed members. With cooperatives such as ZFSC, the idea of attracting youth and increasing rural income will hardly be achieved unless intensive production measures are implemented, and competent training is given to the members. This can be done through hiring expert managers or specialised agricultural extensionists, for example. This can also have other benefits, such as creating or instilling an entrepreneurial spirit in the youth and giving them sound practical experience in intensive farming, which could breed a generation of black commercial farmers. Given the case of ZFSC, it is recommended that specialist extension officers be employed to improve production, ultimately improving income, and attract young people. However, feasibility studies would need to be conducted before commencing with such an idea. Further, research with detailed data will go a long way in giving a full picture of the causes of failure in ZFSC, as this study has partially looked at one possible reason with limited information. Besides poor productivity, there are other possible factors related to why agricultural cooperatives fail, such as rural-urban migration, high operational costs, drought, poor market prices, unrealistic expectations and poor agricultural and management skills. Future work could explore these factors with sufficient data and statistical analysis.

\section{ACKNOWLEDGEMENTS}

Financial assistance was received from the National Research Foundation (NRF) and the Swiss National Science Foundation (SNSF). The opinions expressed and conclusions drawn are those of the author and are not necessarily to be attributed to the aforementioned funding bodies.

\section{REFERENCES}

ALIBER, M., GWALA, L., YUSUF, F., RAHIM, A., MUSHUNJE, A., ARWARI, M., MAKHUNGA, Z. \& SHILIGA, Z. 2017. Government and Small-scale Agriculture: Understanding the Successes and Failures in Respect of Learning, Planning and Implementation. Research report. Available at http://psppdknowledgerepository.org/component/jdownloads/download/287- 
government-and-small-scale-agriculture-understanding-the-successes-and-failures-inrespect-of-learning-planning-and-implementation. Accessed: 16 February 2018

ALIBER, M. 2019b. Forms of agricultural support and the 'culture of dependency and entitlement'. Agrekon, 58(2):141-153

BAIYEGUNHI, L.J.S., MAJOKWENI, Z.P. \& FERRER, S.R.D. 2019. Impact of outsourced agricultural extension program on smallholder farmers' net farm income in Msinga, KwaZulu-Natal, South Africa. Technology in Society, 57: 1-7

BLAIR, D., SHACKLETON, C.M. \& MOGRABI, P.J. 2018. Cropland abandonment in South African smallholder communal lands: land cover change (1950-2010) and farmer perceptions of contributing factors. Land, 7(121): 1-20

CHIBANDA, M., ORTMANN, G.F. \& LYNE, C. 2009. Institutional and governance factors influencing the performance of selected smallholder cooperatives in KwaZulu-Natal. Agrekon, 48(3): 239-315

COOK, M. \& ILIOPOULOS, C. 2000. Ill-defined property rights in collective action: the case of US agricultural cooperatives. In: Menard C (ed). Institutions, contrasts and organisations: perspectives from New Institutional Economics. London, Edward Elgar Publishing

CHRISTOPLOS, I. 2010. Mobilising the potential of rural and agricultural extension. Rome: FAO

CHETENI, P., KHAMFULA, Y. \& MAH, G. 2019. Gender and poverty in South African rural areas. Cogent Social Sciences, 5(1): 1586080

DEPARTMENT OF AGRICULTURE FISHERY AND FORESTRY-DAFF. 2015. The $4^{\text {th }}$ annual report on status of cooperatives in agriculture, forestry and fisheries, 2014/1. Pretoria

DEPARTMENT OF TRADE AND INDUSTRY-DTI. 2012. Integrated strategy on the development and promotion of cooperatives: promoting an integrated cooperative sector in South Africa 2012-2022. Pretoria. Retrieved online at: http://www.thedti.gov.za/economic_empowerment/docs/coops/legis_policy/Integrated _Strategy.pdf. Accessed on 12 September 2018

D'HAESE, C. \& BOSTYN, F. 2001. The strategic challenges confronting agricultural cooperatives in South Africa: the growing need for transformation into agricultural companies. Agrekon, 40(1): 1-12

DE LANNOY, A., GRAHAM, L., PATEL, L. \& LEIBBRANDT, M. 2018. What drives youth unemployment and what interventions help? A Systematic Overview of the Evidence and a Theory of Change. High-level Overview Report 
DE LA HEY, M \& BEINART, W. 2016. Why have South African smallholders largely abandoned arable production in fields? A case study. Journal of Southern African Studies, 43(4): 753-770

DLAMINI, T.R. 2010. Collective farming: elements constituting an effective agricultural cooperative, the case of three co-operatives in the umgungundlovu district. Masters' Dissertation, University of KwaZulu-Natal, Pietermaritzburg

DYALUVANE, N. 2015. The role of agricultural co-operatives in food security in the Eastern Cape, province of South Africa: the case of the Nkonkobe Local Municipality. Master of Soc. Sci. dissertation, University of Fort Hare

EMANUEL, O.A. \& NHLANHLA, N.M. 2014. An examination of the success factors of cooperative- run agricultural schemes: a case study of Intlantsi Agricultural Secondary Co-operative Limited. International Journal of Sustainable Development, 7(12):112120

FRANSMAN, T. \& YU, D. 2019. Multidimensional poverty in South Africa in 2001-16. Development Southern Africa, 36(1): 50-79

GENIS, A.J. 2015. Accumulation and differentiation: The dynamics of change in the largescale commercial farming sector of South Africa. Unpublished PhD thesis, University of the Western Cape, South Africa

GWIRIRI, L. C. \& BENNETT, J. E. 2020. Balancing Democracy with Service Delivery: Power Relations, Politics and Accountability in Cooperatives Supporting Emergent Livestock Farmers in South Africa. International Journal of the Commons, 14(1): 123-138

HULL, E. 2014. The social dynamics of labour shortage in South African small-scale agriculture. World Development, 59(1): 451-460

INTERNATIONAL COOPERATIVE ALLIANCE-ICA. 2013. Guidance notes to the cooperative principles. Retrieved online at: https://www.ica.coop/sites/default/files/publication-files/ica-guidance-notes-en310629900.pdf. Accessed on 12 September 2018

LUKHALO, T. 2017. An expenditure review of agricultural extension system in South Africa. Master's Thesis, University of Pretoria

LYNE, M.C., JONAS, N \& ORTMANN, G.F. 2018. A quantitative assessment of an outsourced agricultural extension service in the Umzimkhulu District of KwaZulu Natal, South Africa. Journal of Agricultural Education and Extension, 24(1): 51-64

MAGAGULA, B. \& TSVAKIRAI, C.Z. 2020. Youth perceptions of agriculture: influence of cognitive processes on participation in agripreneurship. Development in Practice, 30 (2): $234-243$

MAGANO, S., MAZISE, A. \& HOFISI, C. 2013. Employment generation by co-operatives: Myth or Reality? Mediterranean Journal of Social Sciences, 4(3):753-763 
MANN, S \& STOINESCU, A. 2020. Exploring Draheim's three dimensions of success in cooperative organizations - the case of collective Alpine summer farms. Annals of Public Cooperative Economics. https://doi.org/10.1111/apce.12309

MANENZHE, T.D., ZWANE, E.M. \& VAN NIEKERK, J. 2020. Performance and sustainability of commercial cooperatives and sole proprietorships citrus farms in Mpumalanga province, South Africa. South African Journal of Agricultural Extension, 48(1): $70-83$

MACHETE, C.L. 1990. Factors contributing to poor performance of agricultural cooperatives in less developed areas. Agrekon, 29(4): 305-309

MACHETE, C.L. 2004. Agriculture and poverty in South Africa: Can agriculture reduce poverty? Paper presented at the overcoming underdevelopment conference held in Pretoria, 28-29 October 2004

MAZIBUKO, K.J. \& SATGAR, V. 2009. International Cooperative Experiences and Lessons for the Eastern Cape Cooperative Development Strategy: A Literature Review. ECSECC Working Paper Series No. 5, East London

MOJO, D., FISCHER, C., \& DEGEFA, T. 2017. The determinants and economic impacts of membership in coffee farmer cooperatives: Recent evidence from rural Ethiopia. Journal of Rural Studies, 50: 84-94

NATIONAL PLANNING COMMISSION_NPC. 2011. The National Development Plan: 2030, Pretoria

NEFALE, T.A. 2016. The Role of Agricultural Cooperatives in Poverty Reduction: A Case Study of Selected Cooperatives in the Four Local Municipalities of Vhembe District Municipality, Limpopo Province, South Africa. MSc. Agric. Dissertation, University of Venda

ORTMANN, G.F \& KING, R.P. 2006. Small-scale farmers in South Africa: can agricultural cooperatives facilitate access to input and product markets? Staff paper P06-4, January 2006, Department of Applied Economics, College of Agricultural, Food and Environmental Sciences, University of Minnesota, St Paul

ORTMANN, G.F. \& KING, R.P. 2007. Agricultural cooperatives I: History, theory and problems. Agrekon, 46(1): 40-68

PATEL, L., KHAN, Z. \& ENGLERT, T. 2020. How might a national minimum wage affect the employment of youth in South Africa? Development Southern Africa, 37(1): 147161

SEBHATU, K.T., TAHERI, F., BERHANU, T., MAERTENS, M., VAN PASSEL, S. \& D'HAESE, M. 2020. Beyond focus: Exploring variability of service provision of agricultural cooperatives. Annals of Public and Cooperative Economics, https://doi.org/10.1111/apce.12301 
STATISTICS SOUTH AFRICA. 2015. National and provincial labour market: youth Q1. 2008-Q1: 2014. Statistical Release P 0211.4.2. Statistics South Africa. Pretoria

STATISTICS SOUTH AFRICA. 2017. An examination of absolute poverty between 2006 \& 2011. Pretoria

STATISTICS SOUTH AFRICA. 2020. Quarterly labour force Survey: Quarter 4: 2019. Statistics South Africa. Pretoria

TERBLANCHE, S.E. 2008. Towards an improved agricultural extension service as a key role player in the settlement of new farmers in South Africa. South African Journal of Agricultural Extension, 37: 58-84

THABA, K. 2016. Analysis of factors affecting proper functioning of Smallholder agricultural cooperatives in the Lepelle Nkumpi Municipality, Limpopo province, South Africa. MSc. Agric. Dissertation, University of Venda

UYS, G. 2018. Chicken housing - get the basics right! Farmers Weekly, 7 June

VAN DER WALT, L. 2005. The resuscitation of the cooperative sector in South Africa. Paper prepared for the International co-operative Alliance xxi, International Cooperative Research Conference. Cork Ireland, 11-14 August 2005

VAN NIEKERK, J.A.S. 1988. Cooperatives theory and practice. South African Agricultural Union, now known as AgriSA. Pretoria

WESSELS, J. \& NEL, E. 2016. A new co-operative revolution in South Africa? Reflections on the outcomes of state support in the Free State Province. Local Economy, 31(1-2): 187203

YOBE, C.L., FERRER S.R.D. \& MUDHARA, M. 2020. Measuring the financial efficiency of agricultural cooperatives in South Africa: an application of the Simar-Wilson methodology. Agrekon, 59(3): 269-286

ZANTSI, S. 2016. The influence of aspiration in changing livelihood strategies in rural households of Ndabakazi villages in the Eastern Cape. MSc. Agric. dissertation, University of Fort Hare, Alice

ZANTSI, S. \& BESTER, B. 2019. Farming households' livelihood strategies in Ndabakazi villages, Eastern Cape: what are the implications to agricultural extension services? South African Journal of Agricultural Extension, 47(4): 120-134 